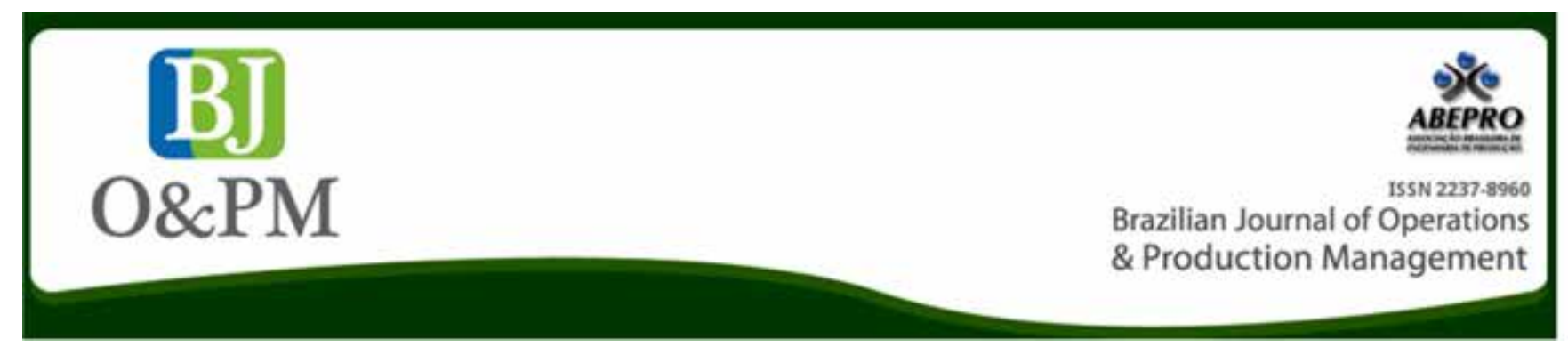

\title{
CREATIVE INDUSTRIES IN CHILE, THE CASE OF ANIMATION
}

María Graciela Severino mseverinoemergencia@gmail.com Pontificia Universidad Católica de Chile, Santiago, Chile.

\begin{abstract}
The present study is a characterization of the creative industry in Chile, the process in which it currently is, and the specific case study of the animation industry in Chile. Given the lack of official data on the impact of this creative sector in Chile's economy, the need to develop activities arose, associated with the collection of consistent and reliable data on the creative economy in Chile. To be able to exemplify and understand the impact of the aforementioned sector, previous studies and methodologies were used, and direct data collection from the sources, as well as secondary sources, were analyzed. The results of this study reveal favorable practices and data for future market research.
\end{abstract}

Keywords: Creative Industries in Chile; Cultural Industries in Chile; Animation in Chile. 


\section{INTRODUCTION}

To be able to start a correct characterization of the creative industrial sector of Chile, it is necessary to begin by knowing some general ideas that provide interesting aspects about what Chile is and where this Creative Industry is located.

Chile is a country that has developed a lot during the last 3 decades, standing out for some concept that the Image Foundation of Chile (Fundación Imagen de Chile, 2017) has defined as "Diversity, tradition, progress and reliability". Referring to the concepts that Chile positions in the world as they are to own a territory of extremes, where the most arid desert coexists with millenary ice, an immense ocean and a mountain range that functions as a backbone. In addition, it is defined by the vocation of progress, associated with a constant search to innovate and develop economically. The last of the most important axes is to be a country with which reliable links can be established, based on their stability and seriousness in acting.

These concepts have been part of a strong strategic work and positioning where the public and the private sectors collaborate strongly.

It is important to mention that, in 2010, Chile joined the Organisation for Economic Co-operation and Development (OECD), considered the group of richest and most developed countries on the planet, being the first country in South America to join it. For Chile, this incorporation meant recognition of its two decades of strengthening democracy, its sustained economic growth, etc. It was also a source of pride to successfully pass the tests that the OECD applied to the country regarding investment, the fight against corruption and environmental issues, among others.

On the other hand, in 2017, the United Nations Development Programme (Programa de las Naciones Unidas para el Desarrollo - PNUD, 2017) published the book Desiguales, which presented the latest research regarding the enormous inequality gaps present in Chile's economic development. The aforementioned research shows that $33 \%$ of the total income of the country is captured by the richest $1 \%$ of the population. And that within that select privileged group, $19.5 \%$ of the country's total wealth is concentrated in the richest $0.1 \%$ of the population. This group is concentrated in approximately 20 economic groups and its investment is distributed in various economic activities. Its high power in the financial management of the country is also transformed into high political influence.

Chile's tax rates are much lower than in other OECD countries, and that is a great motivation to attract foreign investment.

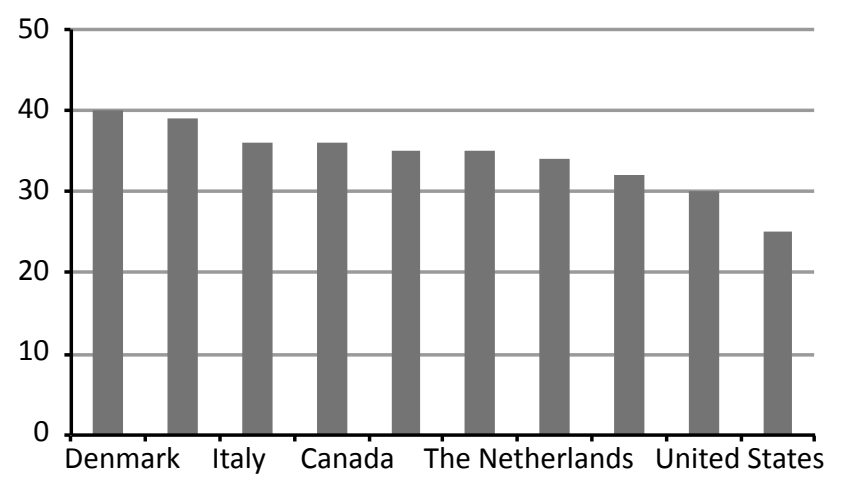

Figure 1. Average rate of income tax on people in 10 countries Source: OCDE (2011), Servicio impuestos internos Chile

Looking into the Chilean Creative Industry it is important to clarify that the existing measurements are initiated by an effort originated mainly by the National Council of Culture and the Arts, currently the Ministry of Culture, Arts and Heritage, which pushed for the creation of a satellite account, in order to be able to measure the incidence of creative industries in the economy.

The current Gross Domestic Product (GDP) of Chile (2016) is US $\$ 247$ billion, and its per capita GDP index is US $\$ 13,793$. This is obtained through the "System of accounts", fostered by the UN, endorsed by the OECD, the IMF and the World Bank. It is divided into 14 activities, where the Creative Industry is not included but diluted in the various activities. That is why Chile, although it does not have a satellite account yet, has made several attempts to develop similar instruments in order to develop its own satellite account for the Creative Industry sector.

\section{THE CREATIVE INDUSTRY IN CHILE}

The presidential decree signed by the president in Chile in 2015, which instructs the construction of an inter-ministerial Committee for Creative Economy, crowns all the efforts that for several years sought to install creative economies in the public agenda. However, for this, it had to be validated with data that, as mentioned in the introduction, allowed for something similar, despite the fact that they were not part of a satellite account.

The first official statistics of the cultural sector began in 1997 with the Yearbook of Culture and Media published by the National Institute of Statistics. From there, the agency publishes annually a report on cultural statistics.

However, it is in the year 2014 that the mapping of the creative industries in Chile is carried out by the hands of the Council of Culture; later they will integrate other organisms 
belonging to the Interministerial Committee of Creative Economy in the data collection (CNCA, 2014).

Based on these investigations, it was possible to determine that the creative industries in Chile contributed more than $2 \%$ of the national GDP and advanced at a growth rate of $24.7 \%$ between 2010 and 2013 , higher than the $14.1 \%$ of the national growth rate of the country between those years (CNCA, 2017a).

In the comparison to the other sectors of different economic activity, it was possible to determine that this sector contributed similarly to the agribusiness sector (2.6\%) and to superior sectors, such as fishing $(0.4 \%)$ or drinks and tobacco (1.6\%).

Table 1. Sectorial Gross Domestic Product (GDP), Chile 2013

\begin{tabular}{ccc}
\hline Sector & Contribution & $\%$ \\
\hline Mining & $\$ 15.260 .963$ & $11,1 \%$ \\
Housing services & $\$ 7.005 .907$ & $5,1 \%$ \\
Transportation & $\$ 5.836 .762$ & $4,3 \%$ \\
Agricultural/Forestry & $\$ 3.595 .871$ & $2,6 \%$ \\
Creative & $\$ 2.181 .966$ & $2,2 \%$ \\
Drinks and Tobacco & $\$ 2.162 .576$ & $1,6 \%$ \\
Fishing & $\$ 546.694$ & $0,4 \%$ \\
\hline Total GDP of Chile & $\$ 137.229 .576$ & \\
\hline
\end{tabular}

Source: Consejo Nacional de la Cultura y las Artes - CNCA, 2017a

Another factor that characterizes the creative sector is the number and size of formalized companies. It should be noted that, in this industry, unlike other more traditional, there is a high percentage of people who participate in it for its high value in social capital and, while they are relevant actors for the industry, several of them are not included in the sample for working informally. So far, it is not possible to determine the size of the informal contribution to the creative industries with concrete data. The reasons are varied, such as transactions without registration, not valued or invoiced by different economic codes.

On the other hand, employment in the creative sector in Chile is measured by the National Institute of Statistics through the Casen survey, which allows them to declare professions and creative trades according to the ISCO revision 08 codes, present in the framework of cultural statistics of United Nations Educational, Scientific and Cultural Organization (UNESCO, 2009).

From this measurement, it was determined that the number of people who claim to have some creative profession or cultural occupation for the year 2015 was 496,425 people, corresponding to $6.6 \%$ of the total employed workers.
Table 2. Companies from the creative cultural sector. Chile, 20052014

\begin{tabular}{ccc}
\hline Year & $\begin{array}{c}\text { Companies creative } \\
\text { sector }\end{array}$ & \% from total \\
\hline 2005 & 29.362 & $3,4 \%$ \\
2006 & 31.858 & $3,6 \%$ \\
2007 & 31.699 & $3,5 \%$ \\
2008 & 32.522 & $3,6 \%$ \\
2009 & 33.532 & $3,6 \%$ \\
2010 & 34.253 & $3,7 \%$ \\
2011 & 35.682 & $3,7 \%$ \\
2012 & 36.709 & $3,7 \%$ \\
2013 & 38.259 & $3,8 \%$ \\
2014 & 39.943 & $3,8 \%$ \\
\hline Source: Consejo Nacional de la Cultura y las Artes - CNCA, 2017a
\end{tabular}

Source: Consejo Nacional de la Cultura y las Artes - CNCA, 2017a

Table 3. Size of companies in the cultural sector. Chile, 2014

\begin{tabular}{cc}
\hline Size & Cultural sector 2014 \\
\hline Big & $1 \%$ \\
Median & $2 \%$ \\
Small & $15 \%$ \\
Microentreprise & $70 \%$ \\
No sales/NO info & $12 \%$ \\
\hline
\end{tabular}

Source: Consejo Nacional de la Cultura y las Artes - CNCA, 2017a

However, people who declare themselves as workers in the cultural sector may be working in activities not linked to the creative sector. For various reasons, it is possible for cultural workers to also execute other economic activities.

All the institutional attempts to raise information for the development of public policies culminated in a National Plan for the Promotion of the Creative Industry (Plan Nacional de fomento a la economía creativa), launched in 2017 (CNCA, 2017b) and which seeks the coordinated development of the sector. To this end, eight ministries participated (Economy, Development and Tourism, External Relations, Education, Social Development, Labor and Social Welfare, Agriculture, Finance, and Culture) where the objective was to design a diverse, dynamic, and versatile productive exporting matrix. They thus generated a new way of seeing the creative sector, by generating a tool to articulate institutions and support instruments.

\section{THE CASE OF ANIMATION IN CHILE}

A correct way to characterize a sector is to begin with its nature of production. Unlike other creative sectors, animation is part of the audiovisual sub-sector. This sector has 
begun to have robust measurements since the beginning of the 2000s, always being divided as cinema and television. The first measurements were directed towards the cinema, which in 1989 had 140 cinemas and ended the millennium with more than 200 (INE, 2001).

The audiovisual sector began to position itself strongly since the 1990s in Chile, but animation did not go hand in hand. Until 2007, Chile premiered only four animated feature films of Chilean origin and some animated series that were scheduled on open television in the morning hours below 9:00 hrs.

\subsection{Flow of operations and data collection}

The National Institute of Statistics highlights the flow of audiovisual operations as a source that organizes the most solid data to establish solid sources of information to gather reliable information.

\subsection{Education}

According to the data collected by the various informants mentioned in table 4 , on the first stage of training, specifically by Ministerio de Educación de Chile (Mineduc) (INE, 2017), only for the animation and videogame career there are 17 careers taught in Higher education centers in Chile; this includes professional institutes, technical training centers and Chilean universities. In total, in 2016, 2,019 students were enrolled, studying for the animation career with educational programs ranging from four to nine semesters.

There are no data on what happened in years prior to this measurement. However, these figures reflect the abrupt change that occurred since 2010.
According to the $\mathrm{V}$ Audiovisual Panorama made by the Pontifical Catholic University of Chile, the animation industry had a self-taught tradition, but has already been professionalized with animation schools (Nuñez et Riveros, 2017).

These institutions are: Universidad Mayor (Digital Animation), Instituto Profesional Santo Tomás (Digital Animation and Multimedia), Arcos (3D Animation), Universidad del Pacífico (Digital Animation and Video Game Design), Duoc UC (Digital Animation) and UNIACC (Digital Communication). The design career of UTEM is also added, which makes it possible to obtain a specialization degree in Visual Communication Design.

Each institution has its particularities regarding the approach and techniques they teach, in addition to the level of specialization the students will achieve.

\subsection{Production of animation in Chile}

In Chile there are several sources of financing for the animation industry, depending on the type of content. The organization of the independent producers allowed visualizing the needs of the sector and opening a dialogue with the institutions, who responded favorably when comparing international cases where the promotion of animation shows clear results that not only contribute to the national GDP but also collaborate in the formation of social capital and the country image. Examples such as Canada were useful in indicating that animation is one of the branches of the creative sector that, due to its versatility, can be part of the important pillars when diversifying the productive matrix.

Until the year 2000 , Chile imported $100 \%$ of the animated films, as the Chilean public prefers animated films in com-

Table 4. Sources of administrative records for the cultural domain Audiovisual and interactive media, according to phases of the cultural cycle. Chile, 2016

\begin{tabular}{|c|c|c|c|c|c|}
\hline \multicolumn{6}{|c|}{ Cultural Domain Audiovisual and Interactive Media* } \\
\hline Subdomain & & Cul & ural and inform & cycle & \\
\hline Radio & \multirow{5}{*}{$\begin{array}{l}\text { Academic stud- } \\
\text { ies (Mineduc) }\end{array}$} & Production (Subtel / scd / & NE / Mutuales c & eguridad) & \multirow{5}{*}{$\begin{array}{l}\text { Comercial- } \\
\text { ización (Adua- } \\
\text { na) (Cadic) }\end{array}$} \\
\hline TV & & $\begin{array}{l}\text { production and exhibition } \\
\text { (CNTV) }\end{array}$ & $\begin{array}{l}\text { Use (Chileac- } \\
\text { tores) }\end{array}$ & $\begin{array}{l}\text { Consumption } \\
\text { (CNTV) }\end{array}$ & \\
\hline Films and movies & & $\begin{array}{c}\text { Creation and production/exhibi- } \\
\text { tion and distribution (Cadic) }\end{array}$ & $\begin{array}{l}\text { Exhibition } \\
\text { (INE / Cadic) }\end{array}$ & $\begin{array}{c}\text { Consumption } \\
\text { (Cadic) }\end{array}$ & \\
\hline $\begin{array}{l}\text { Webseries and social } \\
\text { media }\end{array}$ & & Production (Subtel) & \multicolumn{2}{|c|}{ Consumption (Subtel) } & \\
\hline Videogames & & \multicolumn{3}{|c|}{ No info } & \\
\hline
\end{tabular}

Source: INE, 2017

*MINEDUC: Ministerio de Educación; CNTV: Consejo Nacional de Televisión; CADIC: Cámara de Distribuidores Cinematográficos; CHILEACTORES: Corporación de Actores; ADUANA: Aduanas de Chile; SUBTEL: Subsecretaría de Telecomunicaciones 
Table 5. Titles and audience of the 5 most popular genres in commercial theaters (2012)

\begin{tabular}{cccccc}
\hline Genre & Action & Drama & Comedy & Horror & Animation \\
\hline Number of titles & 47 & 33 & 32 & 14 & 885.694 \\
$\begin{array}{c}\text { Number of public } \\
\begin{array}{c}\text { Average of public } \\
\text { by title }\end{array}\end{array}$ & 5.646 .806 & 2.072 .353 & 1.553 .924 & 4.933 .096 \\
\hline
\end{tabular}

Source: CAEM (2012)

parison with any other genre, doubling the box office in relation to the average of an action movie in cinemas.

The first boom in the development of Chilean animation took place far from the movie theaters; in fact, it has occurred on television. When between 2003 and 2005 the Chilean television channels decided to bet on animated content, and the National Television Council of Chile decided to support them. More than 23 series were produced and issued during that period. Due to its popularity, the Villa Dulce, Diego and Glot and Pulentos series stood out in that period.

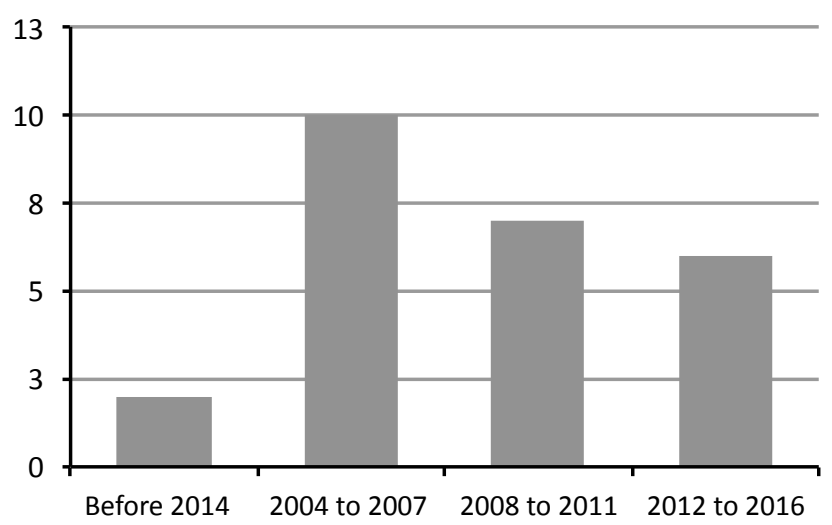

Figure 2. Series premieres in Chile Source: Consejo Nacional de Televisión - CNTV, 2017

Traditionally, the animation industry in Chile has been financed according to the content. If it is of a cultural or children's nature, it follows a path. If it is mainly commercial and promises a good performance in the market, it follows another path. Initially the projects with commercial potential were supported by the state and by the open television channels. However, television support for these animated productions almost disappeared. This is explained by the decrease in sales that the television industry began to experience since 2010.

Currently the largest television channels in Chile are unable to finance animated productions without state support. According to data published in the local press, the three largest television channels in Chile (Channel 13, TVN and Chile- visión) accumulate losses that, since 2014, add up to US \$ 175,000,000.00 (Solminihac, 2017).

Table 6. Sales in UF* of the Chilean Audiovisual

\begin{tabular}{ccc}
\hline Year & Audiovisual & TV \\
\hline 2006 & 4.110 .354 & 19.462 .394 \\
2010 & 4.283 .938 & 15.457 .234 \\
\hline
\end{tabular}

Source: Instituto Nacional de Estadísticas - INE

*UF: Special measure made in Chile

In this context and given the size of the country, which does not exceed 17 million inhabitants, is that many animation producers decided to expand into the international market or diversify their platforms. One of the most successful current co-production cases is that of the Zumbástico Studio series Puerto Papel, directed by Alvaro Ceppi and Hugo Cobarrubias, because thanks to the co-production and broadcast agreements with Globo (Brazil), Señal Colombia (Colombia), TVN (Chile) and Pakapaka (Argentina), added to state contributions, it could be produced with a budget close to 2 Million USD.

Another case that is worth mentioning is the case of Marmota Studio, an animation studio focused on the creation of web content on YouTube, considered the first and most successful web animation page in Chile and Latin America. Thanks to the low cost of producing web content, the study has been able to keep current, reaching more and more people due to broadcast agreements, one with the ETC Television channel, with the Nintendo service, and Nintendo Video, and another with Channel Federator. Currently, Marmota Studio works so that its content reaches more people, preparing content not only for Web but also for television.

Finally, support was provided by Chilean TV channels to the production of animated content disappeared; therefore, today animation producers must look for it outside of Chile. However, this forced departure made the animation sector much more attractive, because, due to its docile and versatile nature, it makes, for example, the dubbing of the contents be much easier than it is for other audiovisual productions. Besides, the work can be done online, thus enhancing the development in regions. This is why there is a long list of 
Brazilian Journal of Operations \& Production Management

Volume 15, Número 3, 2018, pp. 461-470

DOI: 10.14488/BJOPM.2018.v15.n3.a14 kindnesses that the associations of animation producers and the associated festivals have made the institutionality see.

In response, coordinated promotion policies have been created among public agencies, which are presented in the following table, according to the productive phase they support.

\subsection{Business models and financing}

The animated series industry in Chile has had an increase in the last time. At the moment there are dozens of series under development and, at least, 10 in production phase, in addition to 5 feature films in which they will see the light in the years to come. All of them supported by Chilean public financing, in addition to private investment and international funds in the case of co-productions. All seeking to commercialize in the Latin American territory.

The main public funds that support Chilean animation:

\subsubsection{The fund of the National Television Council (CNTV)}

The fund of the National Television Council distributes a total of approximately US $\$ 5,000,000$ among all the applicants. There are exclusive application lines for preschool and children's animation in the production phase. Its focus is financing series that are rich in terms of social and cultural capital. The contents have the privilege of being both a contribution to the culture and being able to dialogue with the market behavior. An annual contest is published and its call generally ends in the months of March and April. Its objective is to collaborate in the production of quality content. It responds and tries to eliminate the trend that currently exists to reduce content for boys and girls. In the year 2017 three animation series, "Mundo Perro", "Chanchiperry" and "Locoslab" were awarded.

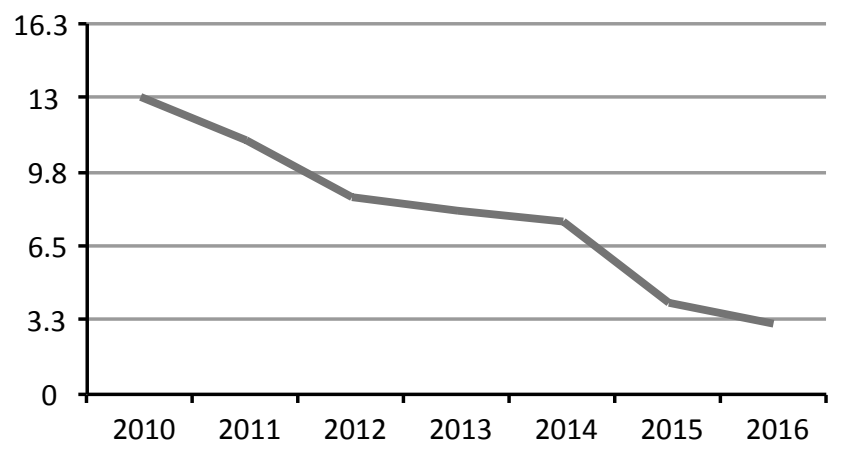

Figure 3. Children's programming offer (4 to 12 years), per year (\%)

Source: Consejo Nacional de Televisión - CNTV, 2017

\subsubsection{Production promotion corporation (CORFO)}

It has a contest to finance the stages of development and aims to create audiovisual projects of fiction, animation, documentary or video games. It is divided into three modalities Unitary projects (1 project up to US $\$ 26,200.00$ ), Series (1 project up to US $\$ 26,200.00$ ) and Business development (from 5 projects, unitary or series of any kind up to US $\$ 123,000.00$ ). The year 2017 awarded five animation projects in the Series category, 24 unitary projects without the possibility of identifying if they are animation and another genre and seven business development projects that seek potential portfolios.

This body depends on the Ministry of Economy and not on culture. That is why the evaluation of the projects of the present contest puts in value the commercial potential of the projects.

\subsubsection{Audiovisual Fund of the National Council of Culture and Arts (CNCA)}

This institution is in charge of financing the culture in Chile. Through hundreds of financing programs it is respon-

Table 7. Map of Chilean financing of animation according to phases of the 2017 cycle.

\begin{tabular}{|c|c|c|c|c|c|}
\hline \multicolumn{6}{|c|}{ Financing according to stage* } \\
\hline Process & Education & Development & Production & Postproduction & Market /Publication \\
\hline Shortfilm & \multirow{5}{*}{$\begin{array}{c}\text { Becas Chile } \\
\text { Mineduc } \\
\text { CNCA } \\
\text { Corfo }\end{array}$} & Corfo/CNCA & \multicolumn{2}{|c|}{ CNCA } & Prochile/CNCA/Corfo \\
\hline TV serie & & Corfo & \multicolumn{2}{|c|}{ CNTV } & Prochile \\
\hline Movies & & Corfo/CNCA & \multicolumn{2}{|c|}{ CNCA } & Prochile/CNCA/Corfo \\
\hline Webseries & & \multicolumn{3}{|c|}{ CNCA } & Prochile/CNCA/Corfo \\
\hline Videogames & & Corfo & \multicolumn{2}{|c|}{ Corfo/CNCA } & Prochile \\
\hline
\end{tabular}


sible for strengthening the area of culture, art, and heritage. Since 2015, it has developed specific financing lines for the animation industry, which has meant an increase in the production of the sector and a big push towards its internationalization process. Currently this fund finances all stages of production, in different lines:

Table 8. Support to animation from Consejo Nacional de la Cultura y las Artes

\begin{tabular}{cc}
\hline Submodality & Amount \\
\hline Script development & US $\$ 6,500$ \\
Re-script development & US $\$ 8,000$ \\
Animation shortfilm & US $\$ 57,300$ \\
Regional animation shortfilm & US $\$ 57,300$ \\
Animation webserie & US $\$ 40,900$ \\
Animation film & US $\$ 320,000$ \\
Distribution & US $\$ 49,100$ \\
Education & - \\
Research & - \\
Participation in festivals and markets & - \\
\hline
\end{tabular}

Source: Consejo Nacional de la Cultura y las Artes

\subsubsection{Ministry of Foreign Affairs, Prochile}

Department in charge of the promotion of the exportable offer of Chilean goods and services, besides contributing to the diffusion of foreign investment and tourism. Currently, through its annual competition, it collaborates in the international positioning of companies with exportable offer, in addition to supporting the visit to fairs and markets of interest. They have an area dedicated exclusively to the creative industries sector and have various support tools.

\subsection{Meeting points}

To facilitate the meeting of international producers in Chile, there is an annual meeting called MAI (international animation market) that takes place within the framework of the Chilemonos Festival where studios, producers, distribution channels and independent workers meet at business tables to get to know each other and discuss current and future projects.

Chilemonos is the main animation festival in Chile and is already positioned as one of the most important festivals in Latin America.

It is financed by almost $70 \%$ of private capital and not only positions the artistic content but also the animation content that does not depend on public financing to exist, such as animation and motion graphics for advertising.

On the other hand, there is the association of animation producers, Animachi, which created a web platform (http:// chileananimation.com/) that hosts information on series, features films and animated short films that are in development, production or that need distribution.

\subsection{Web platforms}

Online platforms have become a very popular way for the creators of Animated series. Netflix, the platform that had 230,000 users in Chile in September of 2014, currently has several Chilean animated series on its grid.

Novasur is the CNTV platform that compiles a large number of children's animated series, with more than 40 Chilean series, selects them or creates them with an educational focus.

On YouTube, there are two Chilean animation studios that generate exclusive series for the Web platform. Marmota Studio: with 1,000,000 subscribers on YouTube and 50,352 likes on their Facebook page. It is a study focused on creating new and original content for YouTube; however, they do not rule out looking for distributors in television channels. Its most viewed video to date is the first episode of the Personas Cetáceas series (which is in its fourth season). In addition, the first season of Personas Cetaceas was dubbed and shown on the successful channel Cartoon Hangover in the United States, under the name of Fin Punch! Where the most visited chapter doubles its Chilean counterpart with 406,922 visits, receiving, in addition, good reviews from the fans of Cartoon Hangover.

On the other hand, the Atiempo studio that, among its four YouTube channels, exceeds one million subscribers on YouTube with its character El Perro Chocolo, with its preschool channel earning the largest number of subscribers in Chile. It is mainly dedicated to upload children's songs.

\subsection{Success cases from Chilean animation}

\subsubsection{Bear Story}

Year of release: 2014. Director: Gabriel Osorio. Responsible study: Punkrobot. Winner of the Oscars 2016 in the category best animated short film.

Funded with CNCA funds for its production and by Corfo for distribution, it costs US $\$ 40,000$. 
The short film shows an old bear that goes out every day from his empty home to the corner of the city, to play a barrel organ with a tin puppet theater, where he tells the story of his family, who lived happily until a circus * took him away from his wife and son.

It was the first Chilean and Latin American short film to win an Oscar. The short film has positioned Chilean animation in various markets around the world. Some associated products such as the illustrated album of the short film led the sales of books during 2016. The feature film based on the history of this short film is currently in production.

\subsubsection{Ogú y Mampato en Rapa Nui}

Premiere Year: 2002. Director: Alejandro Rojas. Responsible Study: Cineanimadores. Box office: 283,788 people.

The story begins when "Mampato", after listening to his father's stories about the mythical island located in the middle of the Pacific Ocean and his enigmas, decides to visit Easter Island, but before, he makes a space-time journey, until prehistory *where he looks for his friend Ogu, a nice caveman. When they get to it, they meet a local girl, Marama. She will be their hostess and companion in the adventures that the trip has for them. Mampato and Ogu, are classic characters of the Chilean comic, created by Oscar Vega and Eduardo Amrstrong, but developed and popularized under the stroke of Themo Lobos.

\subsubsection{Papelucho y el Marciano}

Released in the year 2007, Alejandro Rojas, Director of the Cineanimadores Responsible Studio, in Co-production with Canal 13 Films, Jumbo, Coca-Cola; help with the Box Office of 68,583 people on the first weekend of premiere; With a budget of approximately 1,500,000 USD; and, approximately, 150 people worked on the film.

It all starts when Papelucho, a restless young man with a huge imagination, meets a Martian, with whom he establishes a fast and special friendship. This new friend magically joins him and generates a constant internal conflict between both characters. Papelucho begins to behave strangely in the eyes of the elderly, so he must solve problems that are caused by the Martian and find a solution to send this little friend back to his home. Our protagonist then decides to manufacture a spaceship that will take them to Mars.

\subsubsection{Villa Dulce}

A series released in 2004, directed and produced by: Beatriz Buttazzoni and Francisco Bobadilla. Produced by the
Producer Blanco Films; broadcasted on Channel 13. There were 2 seasons (2004-2005) and a Christmas special. In terms of innovation, Villa Dulce is the first animated series made in Chile, being an impulse for the creation of other series such as Clarita, Diego and Glot, Los Pulentos and El ojo del gato, among others produced in Chile.

Villa Dulce is a community located somewhere in Chile, supposedly in the central zone. This community is governed by a mayor for life called Epifanio Toscano and it is where 13 children between 8 and 12 years plus some adults live. This series stands out for portraying situations that children under 12 live in the country, including situations of "black childish humor", representing reality as seen by children, situations such as the end of the world, reality shows, UFOs, etc.

\subsubsection{Diego y Glot}

Produced in 2003, premiere 2005. Created by Claudio Kreutzberger, and Sebastián and José Correa. Produced by Claudio Kreutzberger. Producer: Cubonegro. Broadcasting House: Canal 13. Project winner of the national television council of 2006.

Diego y Glot is an animated series of a traditional (2D) childish family character, which tells the adventures and misadventures of a typical Chilean neighborhood from the point of view of a child, Diego, his dog Glot and his inseparable friends in the neighborhood which is the stage from where they discover the world that surrounds them.

\subsubsection{Los Pulentos}

Produced in 2003, premiere 2005. Created by Werne Núñez and Sebastián Silva. Directed by Ángel Fucaraccio. Producer: Third Hemisphere. Broadcasting house: Channel 13.

Each episode of the series stands out for showing a musical video of a song of the virtual group at the end. Outside the television broadcast, the group was noted for its popularity among the children, which included live recitals where thousands and thousands of people arrived. At the sales level, the group's albums, Pulentos y Pulentos 2, obtained Platinum and Gold disc levels, respectively.

The musical and television success of Los Pulentos can be attributed to the fact that the songs played by the group are related to themes, feelings and concepts that surround children with an age similar to that of the characters of Los Pulentos. 


\subsubsection{Hostal Morrison}

Year: 2009 and 2011. Directed by Bernadette Ojeda. Producer: Bird. Broadcasting house: Canal 13, Chilevisión, Paka Paka (Argentina), Cartoon Network LA.

Hostal Morrison was one of the winners of the 2009 CNTV Fund, in the children's category. The production obtained \$ $102,966,324$. The series was created and directed by Bernadette Ojeda and was produced by the producer Pájaro. Prior to the purchase of the American channel Cartoon Network, "Hotel Morrison" was shown on Channel 13 and Chilevisión, in addition to going through Pakapaka, the public channel for children in Argentina.

The series tells the story of Celeste Morrison and a group of monsters that intend to turn a house into a hostel for ordinary humans, unleashing situations of terror and humor.

\subsubsection{Personas Cetáceas}

Year: 2013-2016. Created by Matías Latorre. Producer: Bernardita Pasten. Producer company: Marmota Studio. Broadcast House: YouTube - Marmota Studio and Cartoon Hangover, Etc TV and Nintendo Video.

Although in the beginning People Cetaceans would be a short part of Marmota Cartoons, after its premiere on November 29, 2012, it was decided to serialize it. Chapters began to be issued every Friday every 2 weeks as of January 2013. Personas Cetaceas is the first web series of Marmota Studio for its YouTube channel. Currently it has three seasons and eighteen chapters issued. Frederator Studios dubbed this series into English under the name Fin Punch. The theme is the absurd humor of anthropomorphized cetaceans. McLane, the main character of the series, is an office dolphin in a world where cetaceans have been recognized as people. He works as a wage earner while dreaming of conquering humans.

\subsubsection{Flipos}

Year: 2010. Directed by Gabriel Osorio. Producer: PunkRobot Audiovisual Studio. Broadcasting house: Canal 13, Netflix, TvEscola (Brazil), VTR, and Movistar.

In 2008, it obtained a fund from the National Television Council and was sponsored by the University of the Americas. Flipos won two first places in the 2011 Qué Veo Awards, in the categories "Best Children's Series" and "Best Children's Website".

A spaceship that travels throughout the universe and the adventures of four inseparable friends are the ingredients of
"Flipos". The protagonists of the series are Des, Guagua, Lili and Ponk, who travel the universe in their spaceship looking for new planets to explore and live great adventures. In each chapter they meet new friends and solve various problems. At the end, the children review what they have learned through songs, dances and interactive games.

\subsubsection{Puerto Papel}

Year: 2016. Created by Álvaro Ceppi. Producer: Zumbástico Studio. Co-produced: TVN, Señal Colombia, Gloob (Brazil) Pakapaka (Argentina). Broadcasting House: TVN, Señal Colombia (Colombia), Gloob (Brazil), and Pakapaka (Argentina).

It is thanks to the television result and its web work that the program has achieved much international recognition. To begin, they compete for a prize for Best Animation Program for Television at the Annecy Festival, the most important animation event worldwide. In addition, they won the Prix Jeunnesse Children's Television Festival. They won Best Art for Television at the India Catalina Television Awards in Colombia.

The series is about Matilde, a girl who spends the summer in the town of Puerto Papel and thanks to finding a magic coconut that her pirate grandfather found, she acquires some peculiar, and sometimes absurd, magical powers that she cannot control and that change every day in a random way.

\section{CONCLUSION}

The creative industry in Chile, despite having existed since the beginning of the country, having generated resources, work, goods, and positioning, is an industry that does not exist for markets and for investment if it is not capable of being measured. How can it be able to demonstrate the potential if is not able to show itself to the world with reliable data?

From this research it is concluded that the efforts that are currently being made in Chile to create a strategy that makes it possible to take full advantage of the creative sector are well on the way. Chile is focusing its energy on raising data that proves what many intuitions probably have been visualizing.

The creation of a satellite account to identify the real contributions to the GDP of the country, the creation of the National Plan for the Promotion of the Creative Industry, the inter-ministerial coordination, and the contribution of the private and institutions seem to be the first steps for a promising future. 
Finally, the characterization and analysis of the specific case of animation is the clear demonstration of how the articulation of the public and private sectors can bear fruit in the short term if the aim is to focus the conversation on common objectives. Just as the fall of the TV business forced producers to look for other ways outside of Chile, the push of the state to support that momentum was fundamental to supporting business strategies. From the almost null animation production of the year 2010 to winning an Oscar in 2017 , with an Oscar made with almost $10 \%$ of the resources that their red carpet opponents had, it is not luck, but rather the sum of a series of good, humble and strategic practices.

\section{REFERENCES}

Consejo Nacional de la Cultura y las Artes - CNCA (2014), "Mapeo de las Industrias Creativas en Chile. Caracterización y dimensionamiento", Publicaciones Cultura, 1st ed., Santiago Chile.

Consejo Nacional de la Cultura y las Artes - CNCA (2017), Actualización del impacto económico del sector creativo en Chile, pp. 30.

Consejo Nacional de la Cultura y las Artes - CNCA (2017a), "Actualización del impacto económico del sector creativo en Chile", CNCA, Chile.
Consejo Nacional de la Cultura y las Artes - CNCA (2017b), "Plan Nacional de fomento a la economía creativa", CNCA, Chile.

Consejo Nacional de Televisión - CNTV (2017), Anuario Estadístico: oferta y consumo de TV abierta 2016, CNTV, Santiago, Chile.

Fundación Imagen de Chile (2017), Estudio Economía Creativa y Marca País, Santiago, Chile.

Instituto Nacional de Estadísticas - INE (2001), Anuario de cultura y medios de comunicación, INE, Chile.

Instituto Nacional de Estadísticas - INE (2017), “Estadísticas Culturales", Informe anual 2016, INE, Chile.

Nuñez, E.; Riveros, P. (2017), Fantasías animadas de hoy y mañana, in Whittle J.; Núñez E. V Panorama Audiovisual, Pontificia Universidad Católica de Chile, Santiago, Chile. pp. 119-125.

Programa de las Naciones Unidas para el Desarrollo - PNUD (2017), "Desiguales: Orígenes, cambios y desafíos de la brecha social en Chile", PNUD, Santiago de Chile.

Solminihac, V. (2017), “Canal 13, TVN y Chilevisión acumulan pérdidas por US\$175 millones desde 2014", Latercera, Negocios, available from: <http://www.latercera.com/noticia/ canal-13-tvn-chilevision-acumulan-perdidas-us-175-millones-desde-2014/> (accessed 2017 Dec 15)

Received: 04 Apr 2018

Approved: 25 Jul 2018

DOI: 10.14488/BJOPM.2018.v15.n3.a14

How to cite: Severino, M. G. (2018), “Creative industries in Chile, the case of animation”, Brazilian Journal of Operations \& Production Management, Vol. 15, No. 3, pp. 461-470, available from: https://bjopm.emnuvens.com.br/ bjopm/article/view/479 (access year month day). 